\title{
Trade and colonisation in British Central Africa
}

\section{Alfred Sharpe C.B.}

To cite this article: Alfred Sharpe C.B. (1901) Trade and colonisation in British Central Africa, Scottish Geographical Magazine, 17:3, 129-148, DOI: 10.1080/00369220108733232

To link to this article: http://dx.doi.org/10.1080/00369220108733232

曲 Published online: 27 Feb 2008.

Submit your article to this journal 준

山 Article views: 39

Q View related articles ¿ 
TRADE AND COLONISATION IN BRITISH CENTRAL AFRICA.

By Alfred Sharpe, C.B.

\section{(Read at the Society's Hall, Edinburgh, December 13th; also in Glasgow, December 14th.)}

IN addressing you to-night on the subject of British Central Africa, I feel it is especially appropriate that such a paper should be read before a Scottish audience, as the portion of Africa so officially designated-perhaps generally better known as "Nyasaland"-was first explored, and has since been steadily, energetically, and successfully developed chiefly by Scotsmen. Livingstone himself, the greatest of African explorers, spent some of his last years in it, and died there.

The term "British Central Africa" was intended to include that part of British territory north of the Zambesi river, which is bounded on the east by Lake Nyasa and the Shiré river, on the south by the Zambesi districts, north by the Congo Free State and German territory, and west by Portuguese territory. The division of it with which I am dealing to-night is composed of the British protectorate, which lies immediately west and south of Lake Nyasa, together with the country now known as "North-Eastern Rhodesia."

Attention was first drawn to Nyasaland by Dr. Livingstone; and, as is well known, he pointed to the Shire highlands, which lie about 100 miles south of Lake Nyasa, as being one of the most suitable parts of Central Africa for experiments in the way of British colonisation and as a field for missionary enterprise. These highlands lie at an elevation of from 2000 to 4000 feet above sea-level, and have a pleasant, fairly cool climate. The bulk, indeed, of British Central Africa is over the 2000-feet level, the only low-lying portions being the trough of Lake. Nyasa and the Shiré valley. The first commencement of any serious work by Europeans was the formation of mission stations. The Universities' Mission, after some preliminary work in the Shiré highlands, eventually placed their central station on Likoma island in Lake Nyasa. The Free Church of Scotland took the west side of the lake as their field; while the Established Church of Scotland formed their principal post at Blantyre, in the Shiré highlands. After a time the company, now known as the African Lakes Corporation, established itself at Blantyre. This company was, in the commencement, an offshoot of the Scotch Missions, and after, as a preliminary measure, taking up all their transport work, gradually devoted itself entirely to the general trade of the country. Numbers of other firms have since established themselves in the protectorate, both for trading and transport purposes.

In 1887 the cultivation of coffee had already been commenced by the brothers Buchanan (who were originally employees of the Established Church Mission); and was giving promise of being a profitable industry.

Towards the end of 1887 Nyasaland was threatened with a serious check to its progress on account of the advent of Arabs to the north end vOL. XVII. 
of the lake. These people had been extending their influence, south from Tanganyika for some years previously, and had formed the intention of taking the whole of the northern Nyasa districts under their control. In November of that year hostilities broke out between the Arabs and Europeans, which, commencing in the siege by the Arabs of Karonga station, lasted until the year 1889. When the Arabs attacked Karonga, there were seven Europeans there: two of the African Lakes Company's employees, Messrs. Fotheringham and Nicoll (both since dead); Mr. Bain, a missionary of the Free Church (also dead); Consul O'Neil (also dead); his brother-in-law, Mr. Scott; Dr. Tommery, and myself. We succeeded in holding the station for six days till relieved by a force of many thousand Wankonde natives who came to our assistance. In the subsequent fighting both of the Messrs. Moir, joint

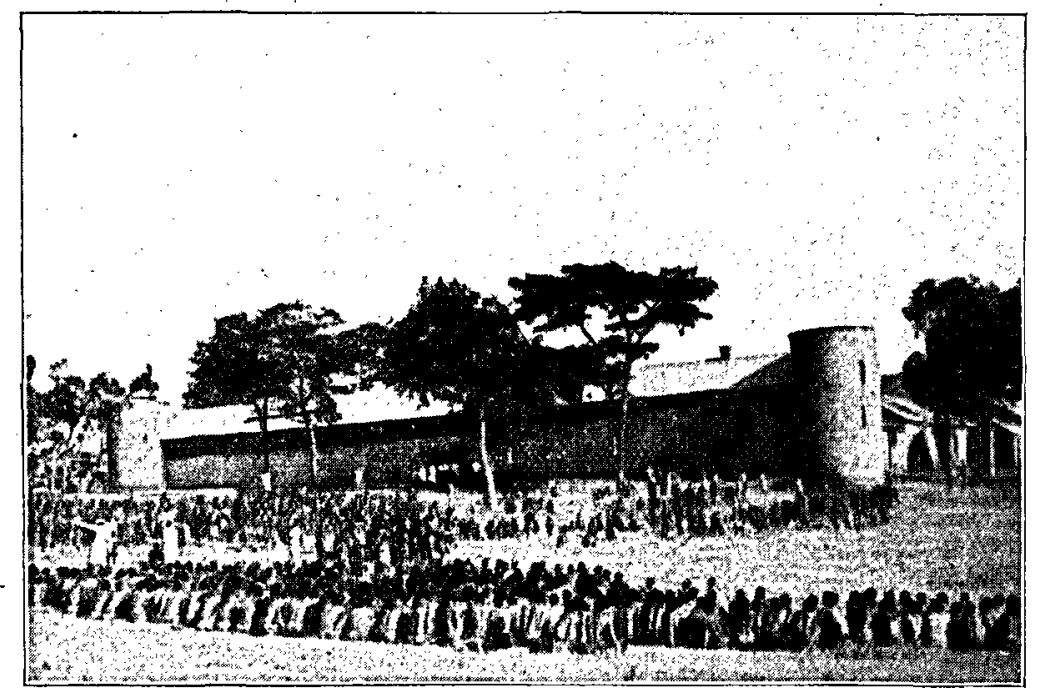

"Mandala," the African Lakes Corporation's Store at Blantyre, in the Shiré Highlands.

managers of the African Lakes Company, were severely wounded, one European was killed, and several others wounded. The result of these operations, however, was to completely check the Arab advance. Hostilities continued desultorily till 1889 , when Sir Harry Johnston, who was sent out by her Majesty's Government to report on the existing state of affairs in the country, arranged terms of peace with the Arab chiefs. In the commencement of 1891 Sir Harry Johnston was again sent out by the Foreign Office, as Commissioner and Consul-General for the territories under British influence north of the Zambesi; and a British protectorate having been declared over the districts lying immediately west and south of Lake Nyasa, an administration was formed, with headquarters at Zomba, about forty miles north of Blantyre. The official name of "British Central Africa" was then given to the country. 
Since 189 1 British Central Africa has progressed and advanced in prosperity : coffee-planting has been largely developed; trade has increased; rubber-producing districts have been exploited; and, at the present date (in addition to coffee), rubber, tobacco, and other products are being exported.

The British South Africa Chartered Company (and Mr. Rhodes personally) contributed largely, in the commencement, to the financial cost of the first steps towards the establishment of an administration and a police force. But for the great interest taken by Mr. Rhodes in the country, and his ready help, its progress in the early days would have been much retarded.

In 1891 there was practically nothing in the shape of revenue locally produced; and although this has steadily grown, until at the present date it may be assessed at some $\mathfrak{E} 40,000$ per annum, Her Majesty's Government have contributed, and still continue to contribute, large sums to provide the difference between the locally produced revenue and the cost of administratiou.

The protectorate was, in the first instance, garrisoned by a force of Sikh soldiers from India, and the work done by them has been beyond all praise. This force has since been augmented by a native regiment, recruited from among tribes with whom we had, during the years 1892, 1893 , and 1894, a good deal of fighting. The Yaos-the finest and most intelligent tribe in the protectorate-gave great trouble up to the year 1895. After the preliminary campaign in 1891 at Mlange against Chikwmbu, we had to fight Makenjira and his many allies-Kawinga, Matapwiri, and other Yao chiefs. Then came troubles in the Marimba country; and in 1894 the Arab difficulties at the north end of Lake Nyasa recommenced. The latter were finally disposed of in 1895 , when the Arab chief Mlosi was captured, and his sub-chiefs defeated and scattered.

In 1897, Sir Harry Johnston having accepted another post, I was appointed to succeed him as Commissioner. In 1898 we were compelled, by the aggressive action of the powerful Angoni chiefs, Mpeseni and Chekusi, to send expeditions against them; their power was broken, and their countries are now being peacefully administered. Of late years there have been few native disturbances in the protectorate, and at the present time there appears to be every prospect of a prolonged peaceful period. The Yaos, Atonga, and most other tribes, have accepted our rule, and also our system of native taxation. In the commencement this was undoubtedly distasteful to them, and although the annual sum at present paid for hut-tax is a trifling one.(3s.), no African likes paying any tax at all if he can help it. As civilisation has progressed, however, the natives have begun to realise, especially in the Shire highlands, that they actually get corresponding advantages, and they now see that life and property are safe in districts where administration officials are within reach. Farther north and west, in the southern Angoni, Chepeta, and Achewa countries, the natives appeár to be less intelligent than Yaos or Atonga, and more similar in appearance and customs to the Mashonas, south of the Zambesi. They are, in some parts, even now averse to all contact with Europeans, and it is only by gradual and careful steps that we are able to get into reasonable touch with them. 
The climate of British Central' Africa cannot be called a healthy one, although perhaps its unhealthiness has been exaggerated. There are many districts, especially in the various high plateaus of Lake Nyasa, where it is pleasant and fairly healthy. The months of May, June, July, August, and September are cool; the worst season of the year being, of course, the rainy one. The rains last more or less from the end of November to the commencement of April, but the really heavy rains are generally experienced during January, February, and March. Ordinary

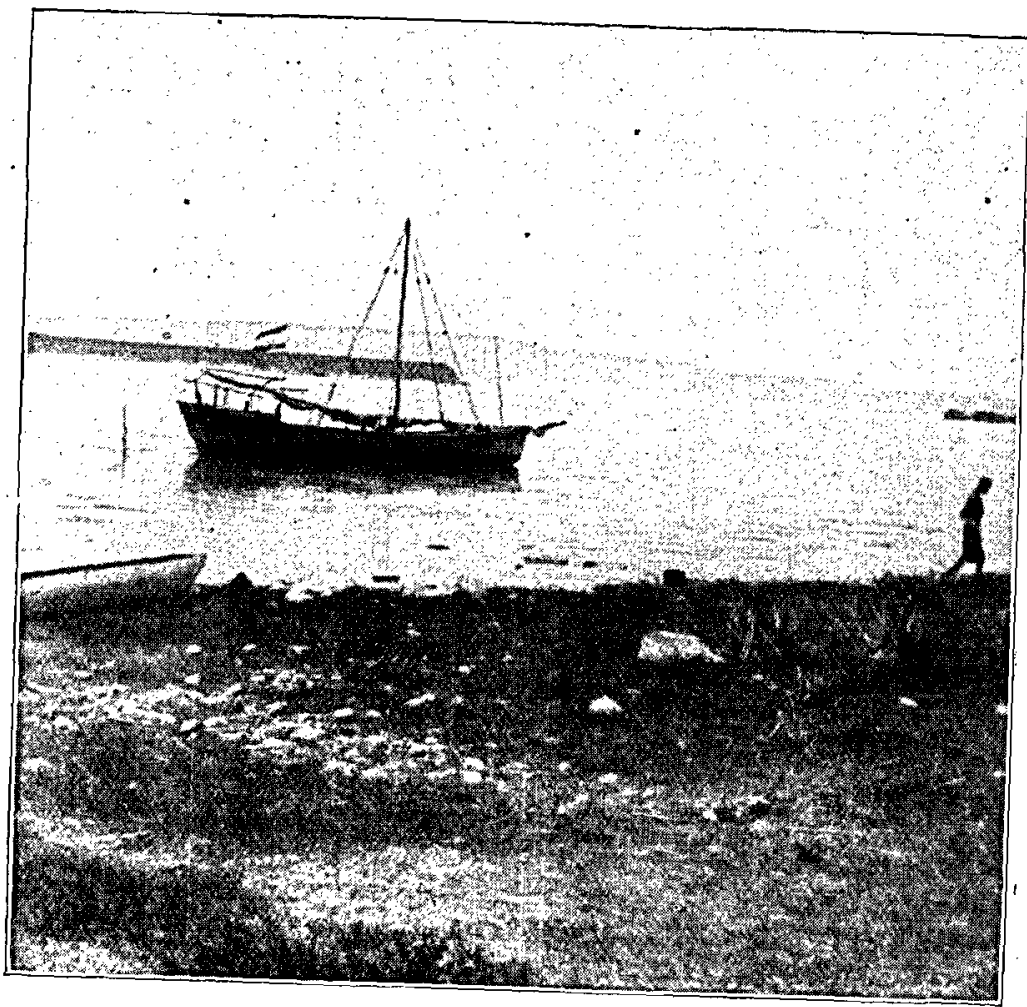

Native dhow on Lake Tanganyika (flying German flag).

intermittent fevers are not dangerous; remittent fever even can be as a rule put up with without very great discomfort; the worst forms of Ofer being bilious remittent, and hæmoglobinuric (or black water) fever. It has come to be more fully realised to our knowledge of malaria. thing which prevents the genuine cold that this is practically the sole tracts of the more elevated portions of tion by white races of large square miles in that continent would of tropical Africa. Thousands of northern Queensland, for instance, if it we livable a land as the bulk of Strenuous efforts are being made to we not; for malarial complaints. 
tion. As you will be aware, H.M. Secretaries of State for Foreign Affairs and for the Colonies have taken a deep interest in the investigations being made. Schools of Tropical Medicine have been established, where it is intended that medical men taking up posts in our tropical colonies and protectorates shall first go through a special course, and thus be prepared to some extent for the diseases they will be likely to meet with. A Medical Commission was sent out by our Government in 1899 to British Central Africa, to inquire into and investigate all questions connected with malarial complaints. Dr. Daniells, the head of the Commission, has recently returned to England after a year's work in the country, and the results of his patient investigations, together with the careful observations of Dr. Douglas Gray, cannot fail to be of great assistance in the now stimulated study of this important question. Specially qualified medical experts have been sent to various spots in West Africa. Liverpool, also, which has such large interests in the West African possessions, has done a great deal to encourage scientific investigations into the cause, prevention, and treatment of malarial fever.

The European population of the British Central Africa protectorate at the present date is somewhere about 450 all told, which may be divided roughly into four divisions-traders, planters, missionaries, and administration officials. The burdens imposed on settlers in the way of taxation are light. The only export duties are on ivory and gold. Import duties are at present 5 per cent. ad valorem (except that one or two articles, such as alcohol and gunpowder, are more highly taxed). Certain goods are admitted free : for example, vehicles, machinery, etc. The amounts paid for licences of various descriptions are moderate.

Although the protectorate is administered from the Foreign Office, it is, I think, practically little different, to all intents and purposes, from a small Crown colony. The administrative headquarters are at Zomba, where the heads of the different departments reside. The chief judicial officer is at present stationed at Blantyre, the commercial centre, and has charge of judicial matters. There are judicial officers at various centres throughout the country who act as magistrates, who also control the district civil police, and carry out revenue and postal duties. English law is administered, as modified and supplemented by Queen's regulations, and, in the case of natives; where possible, by native custom. The Commissioner, in addition to his control of the protectorate, has now a certain amount of supervision over the north-eastern Rhodesian territory belonging to the British South African Chartered Company. In one or two settlements, such as Blantyre, Zomba, etc., which have been proclaimed as "townships," an extent of local government has been placed in the hands of the residents, and this course has proved a satisfactory one. Each township appoints its council (one of the members of which is the collector or magistrate of the district), and this body has placed in its hands the funds raised within the township by rates, for expenditure as may be required. Each district also has its road board, and in the same manner the sum of money out of the road vote which is apportioned to each district is placed in the hands of the board to be expended in what may appear to be the most necessary way. 
With regard to the general trade of the protectorate, the principal occupation of Europeans is coffee-planting. In the year 1899 coffee was

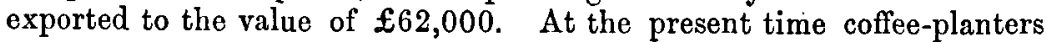
are suffering from a depression in the trade. The prices realised last year were lower than what have been hitherto obtained. I am told, however, that in this respect an improvement is to be looked for. The coffee is of a superior quality and fetches a high price as compared with that grown in most other coffee-producing countries.

In connection with this industry the labour question is becoming a somewhat difficult one. Although there is a large resident native population ready to work for a very low wage, owing to the want of a railway from the head of the navigable Shiré river through the Shiré

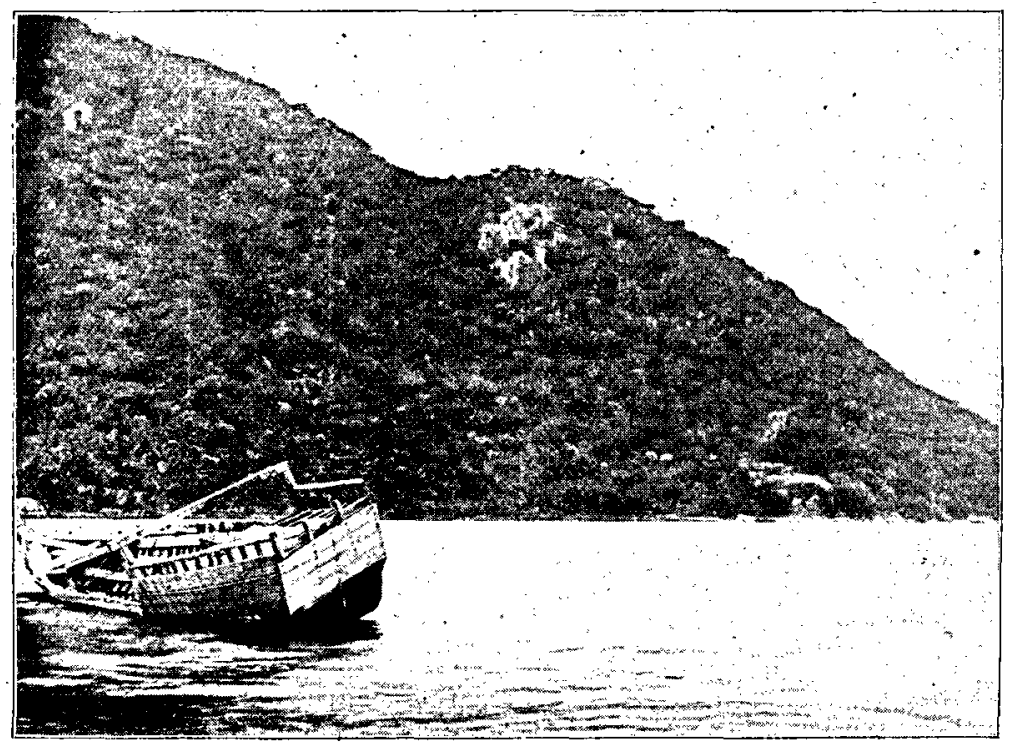

The last of the Lake Nyasa slaving dhows.

highlands to Lake Nyasa, and owing also to the fact that not only is the trade of the protectorate increasing, but that this route into Central Africa is becoming a favourite one for large portions of German Africa and the Congo Free State, the great bulk of the native population is now occupied in carrying loads of merchandise from the lower Shire through the highlands to the upper river, a distance of some seventy miles. Natives prefer work of this description to.work on plantations; and so long as the present demand for native porters on the main road continues, planters will be short of labourers for their plantations. The "transit" trade has very largely increased during the last year or two. Goods going to districts west of Tanganyika and of Lake Mweru mostly go by the Nyasa route, as it is found the quickest and safest. This 
transit trade benefits the transport companies only, and is at present detrimental to the work of the man who develops the country itself, inasmuch as it uses up all the available labour. If a short railway through the highlands to Lake Nyasa were built, this transit trade would cease to be harmful; the protectorate planter would be better able to get native labourers to assist him in carrying out his projects, and the transit trade would benefit merchants and the revenue. In order to explain the position clearly it is only necessary to look at the map of this part of Africa. It will be seen that there is a long line of watertransport extending from the mouth of the Zambesi to the northern extremity of Lake Tanganyika. Here we have a natural line of (comparatively) cheap transport some 1300 miles in length, of which only 270 requires land carriage, the remaining 1030 being by a good waterway, which, commencing at the Zambesi mouth, runs up that river and the Shire to Nyasa, thence 350 miles up that lake, and then (after a portage of 210 miles from Nyasa to Tanganyika) for 400 miles up the latter lake. From the Zambesi mouth to the north end of Nyasa is roughly 650 miles, only 60 of which requires land carriage, i.e. the road which, commencing below the Shiré cataracts, runs through the Shiré highlands and rejoins the river at Matope, above the falls. ${ }^{1}$

The rate of wages for native workers (unskilled) is still only about. 3s. per month, and this low rate has tempted employers of labour south of the Zambesi to endeavour to draw supplies from the protectorate. It has, however, been thought advisable to discourage the going away, of local labour as much as possible, not only on account of the requirements of the industries of the protectorate, but also because it is found that the native himself gains little or no advantage by emigration, and distinctly suffers in many ways.

There can be, I think, no doubt, that, given the continuation of the local labour-supply, coffee-planting in British Central Africa will continue to be, as it has been hitherto, a profitable undertaking. Suitable land can always be obtained in the protectorate at 2s. 6d. per acre. Although small capital and the necessity for great economy were good in the commencement, in that this kept down the price of labour, the time has certainly come. when a greater inflow of capital into British Central Africa is wanted. Many planters have been hampered by having to pay ten, twelve, and fifteen per cent. interest on borrowed money. There are, I suppose, no coffee-producing countries in the world in which there have not been many failures as well as successes, and in British Central Africa, as elsewhere, the success of a plantation depends on the choice of soil, aspect, altitude, etc. Experience seems now to point to the comparatively lower levels, i.e. from 1800 feet above sea-level to 2800 feet, as being best suited for the cultivation of coffee. Over the 3500 level, -many plantations have been unsuccessful. As an example, however, of what can be done in the protectorate, I will instance a very small plantation, the details of which I am well acquainted with :-Thirty-three acres

-1 An article on Railway Schemes in relation to British Central Africa has been contributed by Mr. S. H. F. Capenny and will appear in an early number. 
of land were cleared in July 1887 , and a nursery formed, the plants from which were placed out in the plantation in the commencement of January 1898. This plantation of thirty-three acres produced in July 1900 nine tons of good coffee. The cost of the place, including the purchase-money of the land and everything spent upon it up to the time of picking the crop, was not over $£ 350$. And the valuation of the plantation in 1900 was placed at about $£ 1500$. As a rule coffee-planters have tried to do too much, have been tempted to plant greater areas than they could afford to keep in good cultivation, whereas the smaller estates have been among the most successful.

With regard to rubber, the export of this article has considerably

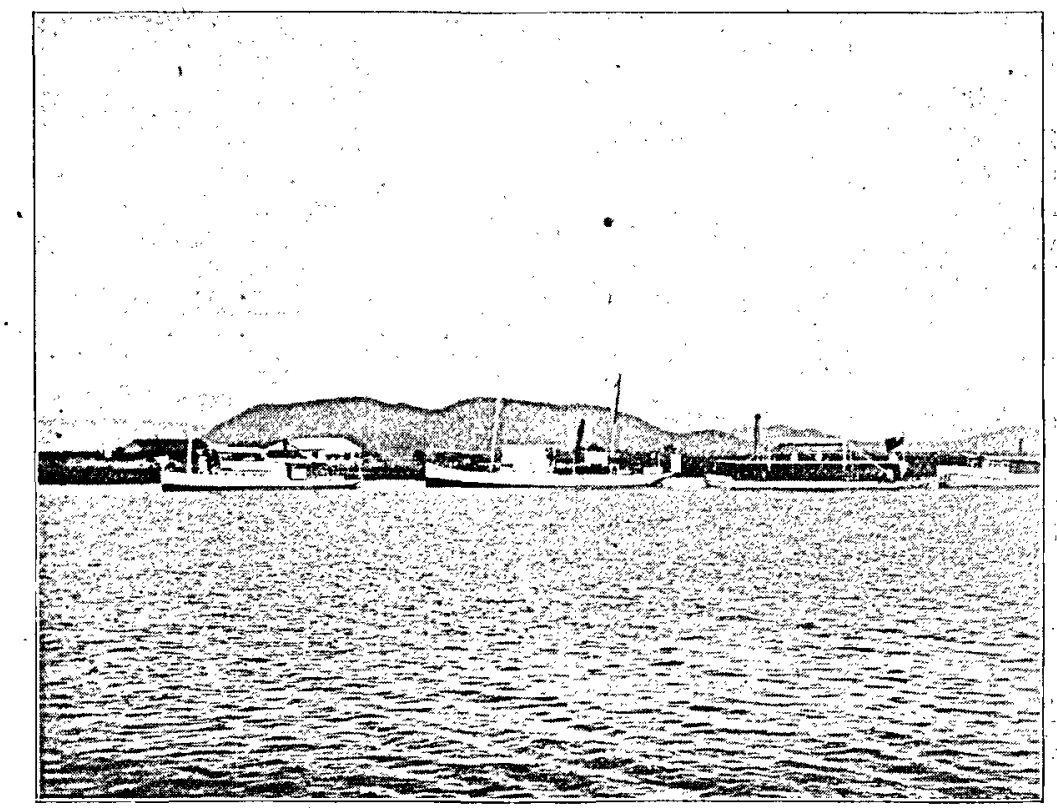

Steamers lying at Fort Johnston (south end of Lake Nyasa).

increased during the last year or two. In 1899 the value exported was a little over $£ 13,000$. There is room for great development in this direction. Up to now the only rubber exported has been that extracted from the Landolphia vine. The juice from this creeper coagulates readily merely by being rubbed on the bare skin of the native collectors, and is therefore very simple to procure. There are a variety of rubberproducing trees in the country, the juice from which requires mechanical coagulation, and which has never yet been collected. The bulk of the rubber exported comes from the Awemba country, and the districts lying immediately south of Lake Tanganyika, and round about Lake Mweru and the Luapula river. In these last-named districts there is as 
yet a certain difficulty in collection, on account of the extreme apathy of local natives, and their disinclination for work of any description. When a rubber-trader enters a district he has little difficulty, at first, in getting the natives to collect and bring him rubber in exchange for trade goods. After a time, however, having procured what calico and trade they need at the moment, nothing will induce them to do more work. This, of course, is the old story in Africa. The wants of the natives being so few, it is difficult to get them to settle to any steady form of work.

Tobacco, although at present only a small export, has a promising future. In 1898 the export was 1780 lbs. only; in 1899 this had risen to $4207 \mathrm{lbs}$. I was recently informed by the only planters who have hitherto grown tobacco to any extent, that they had orders for a monthly supply of $2000 \mathrm{lbs}$. to be sent to Salisbury in Mashonaland, and that inquiries had also been received from various parts of South Africa. The war having disorganised the trade in Transvaal tobacco, that grown in British Central Africa has been able to obtain an entrance into African markets south of the Zambesi, and, as it is in every way a superior tobacco, and can be grown cheaply, the trade should increase. -British Central African tobacco is well suited for pipe and cigarette smoking. American seed has chiefly been used, and the tobacco is cured by fire flues on the American system. The natives themselves grow a considerable amount of tobacco, but it is badly cured.

Chillies have been successfully grown during the last two years, and exported at prices which pay for cultivation.

Ivory as an export has fallen off, and is an article which, under the conditions prevailing hitherto, can never be looked on as a permanent export in any part of Africa. Most of that which now leaves British Central Africa comes from Tanganyika and Mweru districts. The International Convention recently entered into for the preservation of wild animals, birds, and fish in Africa has been a wise step; and if the various signatory powers frame the necessary local laws and regulations for carrying out the provisions of the Convention and vigorously enforce them, this should have the effect of putting an end to the promiscuous slaughter of immature and female elephants, and of rendering permanent for the future a duly controlled trade in an article which would otherwise gradually cease to exist.

Oil seeds are exported from the southern portion of the protectorate. They are grown on or near the banks of the navigable Shire river, and this trade is almost entirely carried on by the Banyans or Indian merchants. Owing to the comparatively small value of oil seeds, they can only staind a cheap rate of transport, and until Nyasaland has a railway, oil seeds could not be grown profitably farther inland than Chiromo, on the Shiré.

Beeswax is exported to some extent, particularly from the southern districts of the protectorate. This is an article of export which might, I think, be largely increased, but the trading firms do not seem to have paid much attention to it as yet. Throughout north-eastern Rhodesia, and especially in the Tanganyika and Mweru districts and in the Awemba country, large quantities of wax could be obtained. 
As soon as a railway has been constructed to Lake Nyasa, there can be no doubt that, by the large reduction in cost of transport to the coast, a number of other products will pay for export. Last year some 800 tons of rice were grown and sold by natives on the south-west shore of Lake Nyasa. The local cost of transport from the south end of the lake

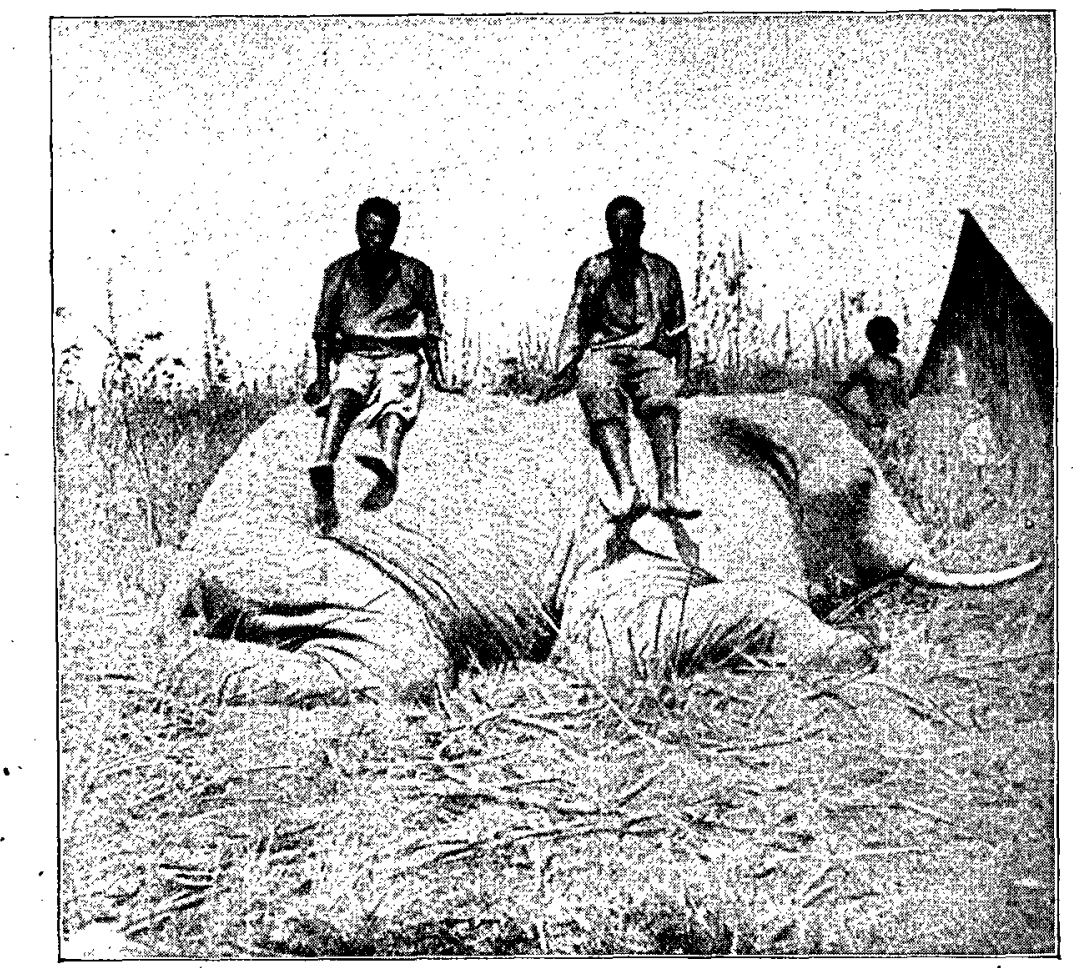

Dead Eleplant (shot at Mweru).

to the sea coast being at present about $£ 8$ to $£ 9$ a ton, rice cannot be exported at a profit.

Ebony and other valuable timbers are found all through the country, but the cost of transport prohibits any trade being done in them.

In 1899 the total value of the protectorate exports and imports was as follows :-

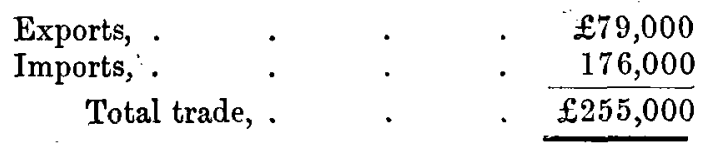

a little over a quarter of a million. This, moreover, does not include the value of goods passing in transit to and from the British South 
African Company's north-eastern Rhodesian territory and the Congo Free State and German territory.

With regard to minerals, British Central Africa is at present almost virgin ground. It has been ascertained that gold exists on the watershed between Lake Nyasa and the Zambesi river; plumbago is found in large quantities and in many localities in the highlands from the north to the south end of the protectorate; and there are large deposits of magnetic iron ore : coal exists near the north end of Lake Nyasa and also near to the lower Shire river. I understand that there is some prospect of an attempt being shortly made to ascertain by actual work and experience whether these southern coal-fields can be profitably worked.

Wheat does well in the country. The variety which has been found to succeed best is a bearded wheat, the seed for which was originally procured from Ujiji on Lake Tanganyika, where the Arabs have grown it for many years past. It is said to be unusually free from rust. The flour used by Europeans on the Tanganyika plateau is locally made from wheat grown by various mission stations south of Tanganyika. On Lake Nyasa the Dutch Reformed Church Mission have for some time past grown wheat and made flour for the local European market. Another Society, the Zambesi Industrial Mission, is now procuring good mill machinery, and intends putting a considerable acreage under wheat, and turning out sufficient flour to provide for the requirements of the protectorate. It is within the bounds of possibility that with cheap carriage to the coast, wheat might be grown for export, provided that labour-saving machinery and apparatus were used.

European settlers are endeavouring to devise some means of transport to the coast which will do away with the necessity for using native carriers. One traction-engine has already been procured, and is working fairly satisfactorily, and more have been ordered. It is very difficult, however, for traction-engines, wagons, carts, or any form of transport at present available to work during the four rainy months-December, January, February, and March; and nothing but native carriers can be used during that period, failing a railway.

Horses and mules thrive fairly.well, and there is a great extent of country west of Lake Nyasa, lying at an elevation of from 3000 to 5000 feet, well suited for cattle breeding. A market is comparatively close at hand, namely in Mashonaland, whither large mobs of cattle have already been driven overland, with in every case little difficulty and a trifling loss en route. The whole of the southern Angoni district is one which would thoroughly suit a pastoral people of simple tastes and accustomed to a colonial life. They could themselves produce most of the necessaries of life, such as wheat, maize, potatoes, coffee, vegetables, beef, mutton, poultry, cheese, butter, milk, etc., and have a ready market for their stock.

Tsetse-fly is only found in certain belts, and the greater part of the protectorate is free from it.

The natives of British Central Africa have progressed in civilisation since the first advent of Europeans. This is especially noticeable round 
- about centres such as Blantyre and Zomba. There are now a number of the more advanced who have bought land from Government and formed coffee plantations. A considerable proportion of natives in the Blantyre and various lake districts can read and write either in English characters or in Arabic, the former having been taught them at the mission schools, and the latter by their Mohammedan teachers. In the Atonga district, on the west shore of Lake Nyasa, it is the exception to find natives who cannot read or write. In this district the Free Church Mission, under the wise guidance of Dr. Laws, has carried out an excellent undertaking. In addition to many years' steady work among the Atonga and kindred tribes, an industrial institution has been established at Kondowe, where natives are apprenticed and taught trades and handicrafts. I recently visited this institution, and can testify to the excellent results which

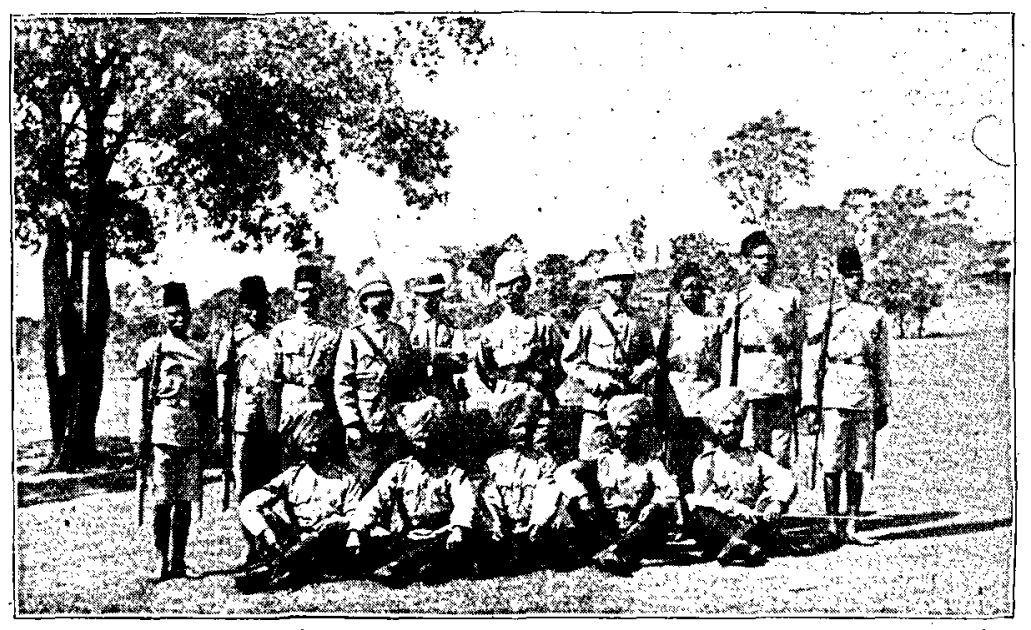

Officers of 1st Battalion Central African Regiment, with Sikh and Native Non-commissioned Officers. (Taken on the parade ground, Zomba.)

have been obtained. At Blantyre some of the natives are now well advanced in cabinet-making and furniture manufacturing.

In new districts of Africa the sudden transition from a life marked by constant wars, oppression by chiefs, and raids by stronger tribes, to a condition of peace and security, has not always in the first instance the best effect on the African. Being no longer in constant fear and ready to carry out whatever his chiefs require, or anxious to do all he can to secure the friendship (i.e. protection) of white men, he becomes at first absolutely lazy, and disinclined to take up any shape of work. Experience shows, however, that as he becomes further civilised his wants increase, and he becomes a more useful member of society.

Some years ago the commencement was made of a locally recruited native regiment. Lieut.-Col. Edwards, who was then Commandant of the Forces in the protectorate, took the first steps toward-its formation, 


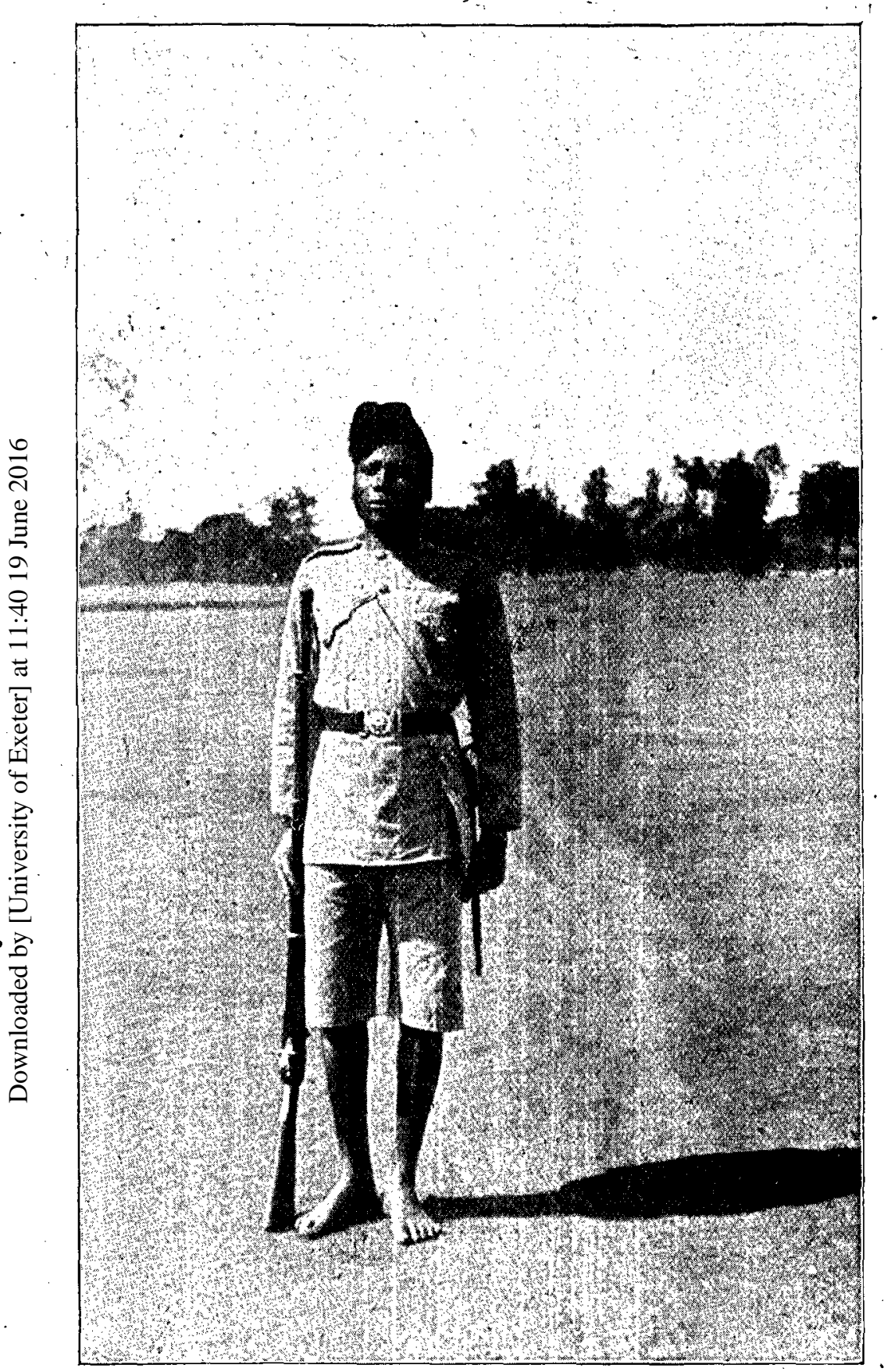

A Private in the Central African Regiment. 
Sikh soldiers being used as drill-instructors. After Col. Edwards's regretted death, this work was taken in hand by Lieut.-Col. Manning, the present Commandant of the Forces, who is also H.M. Deputy Commissioner. He raised and trained a battalion 800 strong, intended for service in the protectorate. Owing to the success which Colonel Manning achieved with this battalion, it was, eighteen months ago, decided by the War Office to recruit a second battalion for service outside the protectorate. The second battalion, nearly 1000 strong, was despatched

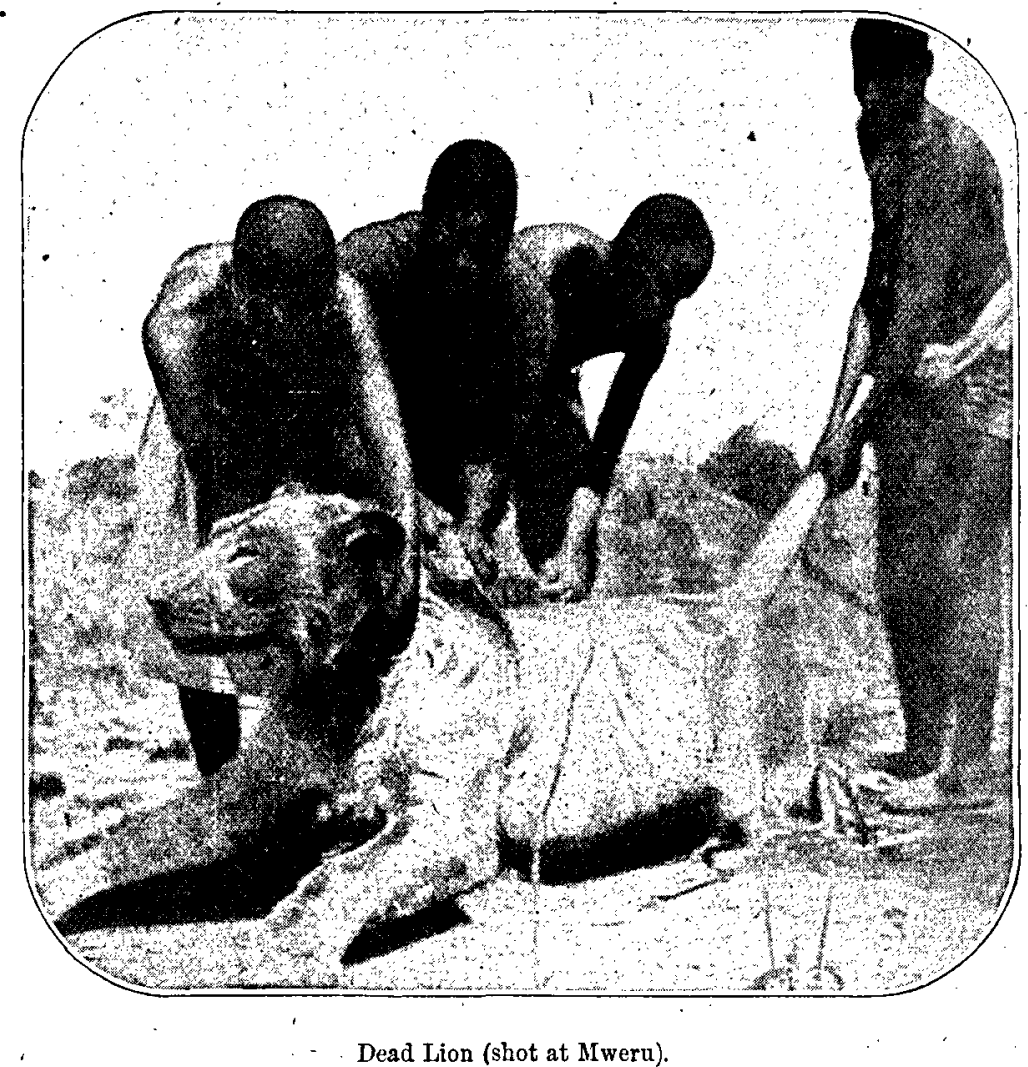

from Zomba in the first instance to Mauritius. From Mauritius they were sent to Somaliland; and a few months after the outbreak of the Ashanti war, 500 men from the second battalion were sent from Somaliland to the Gold Coast, and these, together with a contingent of 300 sent direct from British Central Africa from the first battalion, have been now for some months employed, together with the West African native troops, in suppressing the Ashanti rebellion.

Much has been written and said from time to time on the question of the "colonisation" of the more elevated portions of Central Africa. 
It is true, as I have already said, that there are plateaus where white races, already accustomed to the South African or a similar climate and modes of life, might under existing conditions lead comfortable and comparatively healthy lives; but I do not think that any genuine permanent "colonisation" of any part of Central Africa by British people is possible until some practicable means are discovered of either preventing or greatly lessening the effects of malarial fevers. Of course I use the word "colonisation" in its generally accepted sense. For permanent settlement-such as is carried out in Australasia and the Americas-it is essential, as has often been pointed out, that the colonists should be able to bring out their wives

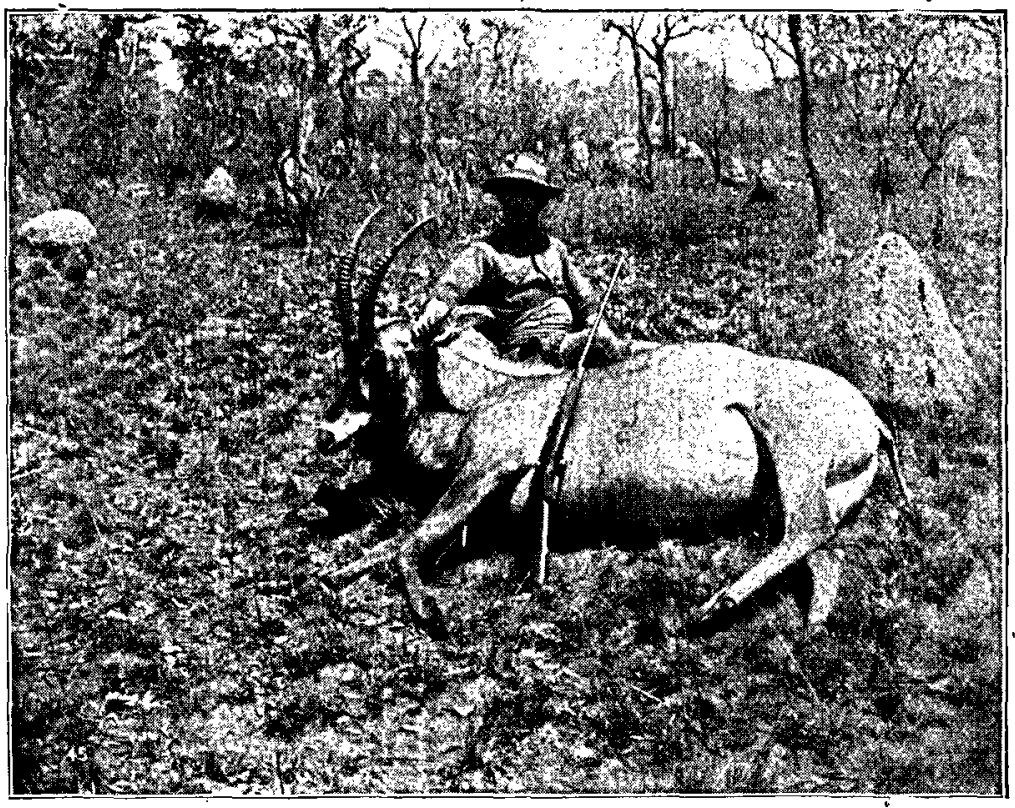

Dead roan Antelope (and Mr. P. Weatherby).

and families, and to rear their children in good health in the colony, without any necessity for periodical visits to other countries for recuperation. Under present conditions this is hardly possible in any part of Central Africa north of the Zambesi. It cannot fail to be seen, therefore, of what extreme importance are all investigations likely to result in more light being thrown on matters connected with malarial fevers and their prevention. The home population is always increasing, and it would appear that the time must come some day when we shall have to make use of every piece of territory we possess in the world which is practicable for colonising purposes.

A colonisation of these Central African districts somewhat similar to our settlements in many purely tropical countries is of course now imme- 
diately possible, all that is required being easy access to the coast, and occupations and trade for the settlers. If another Johannesburg were to be discovered in any of the more elevated portions of British Central Africa, there is no question but that thriving settlements would at once spring into existence.

British Central Africa is in direct telegraphic communication with Europe, via South Africa. This is due to the enterprise of the African Trans-Continental Telegraph Company, who have steadily persevered with their telegraph line. The wire had already reached the south end of Lake Tanganyika when I left Zomba in July, and was being carried up the shore of the lake to the north. By the time it reaches Uganda it is

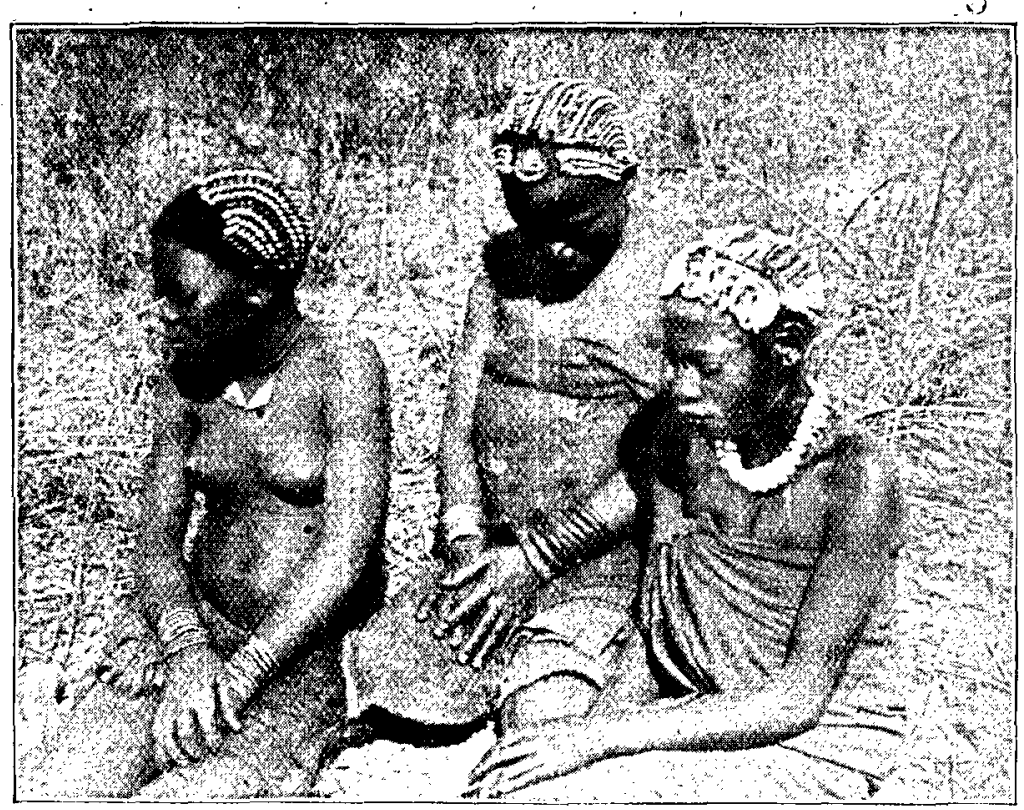

Ulungu Maidens.

probable that the telegraph from Egypt and the Sudan will have been carried so far scuth, and thus Mr. Rhodes's great project of an overland telegraph from the Cape to Cairo is within a reasonable distance of accomplishment. On this line most of the smaller stations on the route are worked by local native operators.

It would appear strange that in a paper dealing with any part of Central Africa there should be no mention of slavery; but as a matter of fact the slave-trade-that is to say, a systematic obtaining and exporting of slaves-may be said in the British Central African protectorate to have.practically ceased. Formerly the most active supporters of this trade. were firstly, of course, the Arabs, and secondly, the Angoni. The former have found it wise to leave Nyasaland alone. The latter (the 
Angoni) have ceased their raids. In southern Angoniland the cause of the change has been the subjugation by the protectorate administration of the two chiefs Mpeseni and Chikusi. In. northern Angoniland the altered condition has been brought about by the influence of Dr. Laws and of other members of the Scottish Free Church Mission. The Yaos beyond our eastern border up to last year still made occasional raids into the protectorate. It will probably require many generations to pass, even in so limited a portion of Africa as Nyasaland, before domestic slavery ceases; but this is a modified form, and as in the more civilised parts of the country it is now clearly understood that every man is legally free if he chooses to be so, great changes are already apparent.

I have had occasion to speak of the work done by the various missions in British Central Africa. In that country the different societies have wisely agreed upon their respective spheres of action, and carry on their work in great harmony. It is a pleasure to me, in looking back through the term during which the administration of the protectorate has been in my hands, to think that my relations with the different societies have been very friendly ones. They have often been able to help me, and I trust that I have also been of some assistance to them.

To sum up the position of affairs in British Central Africa, so far as the past is concerned, it may be shortly said that there has been gradual, steady progress; there has been no sudden and rapid expansion, as in territories south of the Zambesi, where gold-mining has been the chief occupation. Money. has been scarce, and all that has been done has been carried out by those who have had to consider carefully every pound of expenditure, and to first make sure that their money would bring them in a good return. A plentiful supply of cheap labour has been hitherto the best asset of the country.

As to the future, what is required is, firstly and chiefly, a continuation of this supply of labour, and secondly, a larger inflow of capital. A railway - when we get it-will largely help to keep up the labour-supply by releasing large numbers of men now employed on transport work.

I cannot, I think, better conclude this paper than by a few words referring to the death-place of Dr. Livingstone and the history of the rough-and-ready memorial of him left by his African followers. Livingstone, as you are aware, died in 1873 at Chitambo, in British Central Africa, near to the south end of Lake Bangweulu. Beneath a large tree his faithful servants buried his heart, his body being dried and carried by them throughout their journey of many hundreds of miles to the east coast. On this tree they carefully carved an inscription. Nineteen years later a memorial bronze plate, which had been sent by the Royal Geographical Society of England, was left by Monsieur Bià, a French explorer, in the village of Chitambo. This village was then some miles distant from the tree, which, owing to the abandonment by Chitambo of his old site, was hidden in the forest. Bia also. left.with Chitambo a document stating what he had done. In 1894 the English traveller Henry Glave, correspondent of the Century Magazine, reached Chitambo, and after some search discovered the tree and photographed

vou. XVII. 
it. He was shown the paper left by Bià in Chitambo's village, and added a note to it. He found that the bronze plate left with the chief had been stolen by Arabs. A few years later the tree was visited by Mr. Weatherly and Mr. Crawford. In $1898 \mathrm{I}$ proposed to the Royal

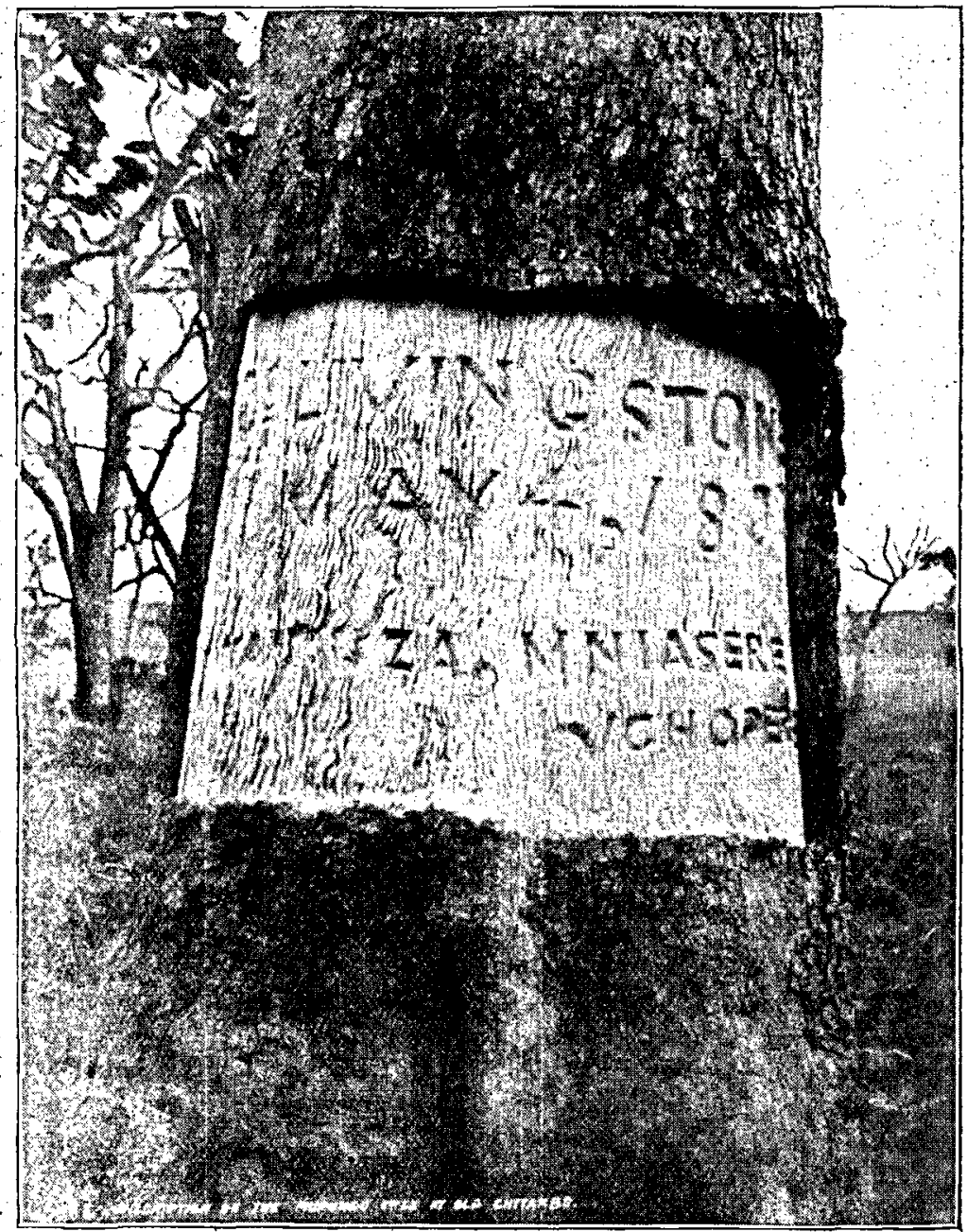

The Tree at Chitumbo underneath which Dr. Livingstone's heart was buried.

Geographical Society that as the tree was reported to be fast decaying, and sure to fall soon, the section bearing the inscription should be cut out, and if possible transported to England; and the Society, acting on the suggestion, authorised me to take the necessary steps to carry this out. On my return to British Central Africa in the end of 1898, Mr. Robert Codrington, Administrator for the British South African 
Chartered Company in north-eastern Rhodesia, offered to visit Chitambo, to cut out the section and despatch it home. This he succeeded in doing, and early in the present year it safely reached London, in a good state of preservation, and was handed by the Company to the Royal Geographical Society, at whose headquarters in London it now rests. Mr. Codrington, after cutting out the section, to temporarily mark the exact spot erected a high iron telegraph pole, the base of which was securely imbedded in the stump of the tree, the pole itself being strongly stayed by telegraph wire. He also took bearings, measurements, and observations, which will prevent the exact locality being ever again lost sight of.

You will be aware that the material has recently been despatched to British Central Africa for the erection of an obelisk on the spot, and I think we can be sure that this monument to the greatest of African explorers will be in future carefully guarded and kept in repair by the European settlers.

Copy of a document handed to R. Codrington by the chief Chitambo at Old Chitambo, 10th May 1899.

\section{Procès-Verbal.}

Le aujourd'hui 6 Juillet 18 quatre vingt douze nous avons réuni dans une grande palabre à Mwege-Kitambo les successeurs de feu Kitambo et environ 500 indigènes à l'effet de leur remettre solennellement la garde d'une plaque de bronze sur laquelle sont gravés les mots :

\section{"DAVID LIVINGSTONE DIED HERE \\ ILALA, IsT MAY 1873."}

Le village où est mort le célèbre docteur anglais se trouve à environ $15 \mathrm{Ko}$. vers le SE. et a été abandonné complètement par les héritiers de Kitambo à la mort de ce dernier.

Perdu au loin et au milieu des grandes herbes, ce n'est plus qu'avec hésitation que les indigènes désignent l'endroit où est enterré le cocur de Livingstone.

La plaque qui fut votée en séance extraordinaire par la Société Royale de Géographie de Londres, en mémoira du grand explorateur a donc été forcément vissée par nous sur un arbre au centre du village de MweGe-KItambo.

Piana-Kitambo, âgé d'environ 17 ans, fils unique et successeur de Kitambo et ses cousins : Mweqe-Kitambo, son tuteur et KalonaA, Chef du village de Masenga, prennent l'engagement formel de respecter et de faire respecter par les sujețs et par leurs successeurs la plaque confiée à leur garde. Ils déclarent en outre que tous les Européens recerront dans tout le pays la meilleure hospitalité.

Leur engagement est consacré par l'octroi d'un présent qu'ils ont reçu et dont ils donnent décharge par le présent procès-verbal établi en double expédition.

Le Chef Piana-Kitamio. (mark) +

Le Chef Mwege-Kitambo. (nark) .

Le Chef Kalonga. (mark) +
Le Commandant de l'expédition du

Katanga.
(signed)
Bia,

Capitaine de cavalerie belge.

Le Second de l'expédition du KatayaA.

(signed)

E. Francqui, Lieut. d’infanterie belge. 


\section{PRÉSENTS DIVERS.}

Un fusil de chasse à 2 coups.

10 kilogs. de poudre fine.

1000 capsules.

2 poires à poudre.

45 pièces de mouchoirs.

3 pièes de guimpe extra.

3 pièces d'américaine.

3 pièces de bleu-stripe.

3 pièces de bleu-prints.

12 crasses de cotonette imprimée.

60 mouchoirs imprimés (ạnimaux).
3 pièces de velours.

3 pièces de soie.

3 pièces de mouchoirs en soie.

1 sabre avec fourreau.

1 grand couteau de chasse. .

3 fez rouges.

3 chapeaux en velours soutaché.

3 parasols noirs, des sonnettes, des: perles, miroirs et des grelots.

Un paquet de clous de cuivre doré.

\section{Village of Mwiwolela, Chiefs Kawai and Tshitambo, July 13, '94.}

Upon my arrival to-day at the tree in the village of Tsнiтамво where the inemorial tablet to Dr. Livingstone was fixed by Capt. Bia and Lieut. Franqui, I found the village had been deserted two years ago on account of the WA-WEMBA raiders, and the plate was stolen by a big slave caravan which left the country between the R. LUAPULA and LAKE BANGWEolo about 18 months ago in charge of two Swahili slave raiders and traders, Kasaki and Karuma.

These two men knew their followers had stolen the plate, and made a boast of having robbed the white man's grave.

Kasaki and Karuma had for many months raided the Iranba Country, and when a large batch of slaves was collected they put them in chains and slaveforks and took them to the Zambezi to Nrunawe, somewhere at the junction of the LoANawa and Zambezi.

I have visited the exact spot where the heart of Dr. Livingstone is buried, and have a photo of the tree, with the inscription, carved by Jacob Wain wright.

The tree is situated about five miles SSW. of the village of Karonga on the . R. Lulimala.

July 13, 1894.

(Signed) E. J. Glave,

Special Correspondent of the New York Century Magazine.

NoTE.-I am indebted to Mr. Weatherly for several of the photographs from which the illustrations which accompany this paper have been produced,-notably that of the tree.-A.S.

\section{THE LATE F. P. PULLAR.}

A Melancholy interest attaches to the paper on the Scottish Lochs which appears in this number of the Magazine, owing to the tragic death of one of the authors, Mr. F. P. Pullar, since the paper was. passed for press. On February 15, while several hundred persons were skating on Airthrey Loch, in the grounds of Airthrey Castle, near Bridge of Allan, the ice suddenly gave way, and a number of people were precipitated into the water. Mr. Pullar, who was a strong, muscular young. 